\title{
Model Efisiensi Pasar: Sebuah Studi Pengaruh Musiman Terhadap Volume Perdagangan Saham Di BEI Emiten Lq 45 Tahun 2010-2013
}

\author{
Oleh: \\ Zul Azmi \\ Staf Pengajar FEB Universitas Muhammadiyah Riau \\ Wenni Hasmita \\ Alumni FEB Universitas Muhammadiyah Riau
}

\begin{abstract}
Abstrak
The objective of this research is to empirically re-examine the influence of seasonal anomaly or calendar effect in financial markets called the Monday effect, week-four effect and Rogalski effect to stock trading volumein Indonesia Stock Exchange.The sample is selected using purposive sampling Technique, the sample consist of twenty four active stock in LQ 45 index during January 2010 through December 2013. The statistic methods which used to test the hypotesis are Analysis of Variance (ANOVA) and Independent Sample t-test.

The results of this study indicate that there is the day of the week effect in IDX. The finding shows that there are different stock trading volume for five trading days. The highest and the lowest volume are observed on Wednesday and Monday. Analysis of week-four effect in IDX does not find the existance of this phenomenon in IDX, this paper shows the Monday effect accurs not only in the fourth week but olso in the first three weeks. Further test shows that Rogalski effect does not exist in IDX, the mean of stock trading volume observed on Monday during April is lower than the rest of the months.
\end{abstract}

Keywords: Seasonal anomaly or calendar effect, Monday effect, week four effect and Rogalski effect 


\section{PENDAHULUAN}

Pasar modal dapat mendorong terciptanya alokasi dana yang efisien karena tingkat likuiditas investasinya memberikan kesempatan kepada investor untuk dapat memilih alternatif investasi yang paling menguntungkan. Pasar modal dikatakan likuid jika investor dan emiten dapat menjual dan membeli surat-surat berharga dengan cepat. Sedangkan pada pasar modal yang efisien, diharapkan harga yang terbentuk di pasar sudah menggambarkan informasi yang ada, sehinggaakan terjadi hubungan yang positif antara risiko yang dihadapi dan keuntungan yang akan diperoleh. Keputusan investasi oleh investor akan berpengaruh terhadap aktivitas perdagangan di pasar modal yang akan tercermin dari perubahan harga, perubahan volume maupun perubahan frekuensi perdagangan yang menyebabkan harga, volume dan frekuensi yang berbeda setiap hari dalam satu minggu perdagangan.

Pada konsep pasar efisien, pasar hanya akan bereaksi sesuai dengan informasi yang tersedia dan perubahan harga bersifat acak (random). Meskipun secara umum konsep ini diterima oleh kalangan akademisi tetapi tidak semua masyarakat keuangan mempercayainya dan berdasarkan penelitian, diindikasikan bila perilaku harga tersebut ternyata bersifat musiman (seasonal) sehingga memberi kemungkinan bagi investor mengikuti pola perdagangan (trading pattern) tertentu. Hal ini merupakan kejadian yang bertentangan dan penyimpangan terhadap hipotesis pasar efisien yang disebut anomali pasar. Anomali pasar merupakan kejadian yang tidak dapat diantisipasi dan mempunyai dampak buruk karena menyebabkan pasar modal tidak lagi menampilkan keadaan ekonomi yang sebenarnya. Berbagai penelitian dalam bidang pasar modal dan perilaku keuangan (behavioral finance) menyatakan bahwa terdapat beberapa gap yang terjadi yang dapat mempengaruhi harga saham diantaranya adalah seasonality/calendareffect, week four effect dan Rogalskieffect.

Penelitian yang dilakukan oleh Antariksa Budileksmana (2005) membuktikanbahwa terjadi Monday effect di BEJ selama periode sampel 1999-2004 akan tetapi Monday effect tidak terkonsentrasi pada hari Senin dua minggu terakhir setiap bulannya, Senin minggu kedua mempunyai return yang paling rendah dibandingkan return pada minggu-minggu lainnya. Return pada hari senin tidak random, dan dapat diprediksi secara sistematis berdasarkan kondisi pasar hari Jumat minggu sebelumnya. Munculnya gejala Monday effect di BEJ tidak stabil dan bervariasi dari tahun ke tahun sepanjang periode 1999-2004. Sedangkan penelitian yang dilakukan oleh Iramani dan Ansyori Mahdi (2006) membuktikan bahwa bahwa rata-rata return terendah terjadi pada hari Senin dengan nilai negatif sebesar - 
0.4994\%, membuktikan terjadinya fenomena Monday effect. Juga membuktikan bahwaweek four effect terjadi di BEJ pada tahun 2005. Hasil temuan ini mendukung teori week four effectyang menyatakan bahwa return pada hari Senin pada minggu terakhir setiap bulannya adalah negatif signifikan. Namun penulis tidak menemukan adanya Rogalski Effect pada bulan April untuk periode pengamatan bulan Januari-Desember 2005.

Siqi Guo Zhiqiang Wang (2007)membuktikan bahwa anomali musiman seperti efek hari minggu, efek positif bulan Maret, dan efek negatif bulan Juli ada di pasar saham Cina. Sedangkan efek semi-bulan tidak terjadi secara signifikan, tetapi efek musiman yang ada tidak terus-menerus terjadi.

Phaisarn Sutheebanjard and Wichian Premchaiswadi(2010)yang melakukan penelitian pada Stock Exchange of Thailand (SET) memberikan bukti empiris bahwa day-of- the-week memiliki dampak yang signifikan pada indeks SET dengan persen tertinggi kesalahan prediksi pada hari Senin dan persen terendah dari kesalahan prediksi pada hari Jumat. Seasonality/calendareffect, week four effect, dan Rogalskieffect selain berpengaruh terhadap return saham dan abnormal return saham, diperkirakan juga berpengaruh terhadap besarnya volume perdagangan saham. Volume Perdagangan memperlihatkan transaksi-transaksi yang terjadi di setiap harinya, ini membantu melihat fenomena dari sisi aktifnya transaksi yang terjadi.

\section{KAJIAN PUSTAKA}

\section{Hipotesis Pasar Efisien (Efficient Market Hypothesis)}

Efisiensi pasar berkaitan dengan hubungan antara harga-harga sekuritas dengan informasi. Suad (2001:264) mendefinisikan pasar modal yang efisien sebagai pasar yang harga sekuritas-sekuritasnya telah mencerminkan semua informasi yang relevan. Dalam hal ini, informasi yang tersedia baik informasi di masa lalu maupun informasi yang dipublikasikan saat ini, serta informasi yang bersifat privat yang beredar di pasar yang bisa mempengaruhi perubahan harga.

Jika harga telah mencerminkan informasi yang relevan, maka harga tersebut akan berubah setelah informasi baru muncul. Artinya, perubahan harga yang terjadi hari ini tidak bergantung kepada perubahan harga yang terjadi di waktu yang lalu. Dengan demikian maka perubahan harga tidak dapat diperkirakan sebelumnya sehingga perubahan harga pada pasar efisien adalah acak (random). 
Secara empiris pasar efisien dibedakan menjadi tiga kategori berdasarkan informasi yang tersedia (Fama, 1970:414):

a. Pasar efisien bentuk lemah (weak form), Pasar dikatakan efisien dalam bentuk lemah jika harga-harga dari sekuritas tercermin secara penuh (fully reflect) informasi masa lalu.

b. Pasar efisien bentuk setengah kuat (semi strong form), Pasar dikatakan efisien setengah kuat jika harga-harga sekuritas secara penuh mencerminkan semua informasi yang dipublikasikan (all publicly available information) termasuk informasi yang berada di laporan-laporan keuangan perusahaan emiten.

c. Pasar efisien bentuk kuat (strong form), pasar dikatakan efisien dalam bentuk kuat jika harga-harga sekuritas secara penuh mencerminkan semua informasi yang tersedia termasuk informasi yang privat.

\section{Anomali Pasar}

Pada anomali pasar (market anomalies)ditemukan hal-hal yang seharusnya tidak terjadi pada pasar efisien. Akan tetapi secara empiris terbukti anomali pasar muncul pada semua bentuk pasar efisien, baik bentuk lemah, semi-kuat, maupun kuat. Anomali pasar adalah suatu kejadian/peristiwa yang dapat dieksploitasi untuk mengasilkan abnormal return/profits.

Dalam teori keuangan, dikenal sedikitnya empat macam anomali pasar. Keempat anomali tersebut adalah (Levy dalam Gumanti, 2011):

a) Anomali peristiwa (event anomalies) terjadi bilamana harga mengalami perubahan setelah adanya suatu kejadian atau peristiwa yang mudah teridentifikasi.

b) Anomali musiman (seasonal anomalies) sangat tergantung pada waktu.

c) Anomali perusahaan (firm anomalies) muncul atau terjadi sebagai akibat dari adanya sifat atau karakteristik khusus dari perusahaan.

d) Anomali akuntansi (accounting anomalies) adalah perubahan dalam harga saham sebagai akibat dari dikeluarkannya suatu informasi akuntansi.

\section{The Day of The Week Effect}

The day of the week effect merupakan perbedaan return antara hari Senin dengan harihari lainnya dalam seminggu secara signifikan. Pada beberapa pasar modal terdapat kecenderungan return terendah terjadi pada hari Senin kemudian meningkat pada hari-hari lainnya. Monday effect adalah salah satu bagian darithe day of the week effect yaitu suatu 
anomali musiman (seasonal anomaly) atau efek kalender (calendar effect) yang terjadi pada pasar finansial yaitu ketika return saham secara signifikan negatif pada hari Senin (Mehdian dan Perry dalam Budileksmana, 2005).

Penelitian di pasar modal Amerika Serikat menemukan bahwa the Monday effect adalah terkosentrasi pada hari Senin dua minggu terakhir setiap bulannya. Hal ini dibuktikan oleh penelitian yang dilakukan oleh Sun dan Tongyang menunjukkan bahwa the Monday effect adalah terkosentrasi pada dua Senin terakhir setiap bulannya. Anomali the Monday effect kemungkinan berhubungan dengan masalah likuiditas dan perilaku investor individu di pasar. Pada hari Senin, investor individual lebih banyak bertransaksi daripada investor institutusional dan permintaan penjualan ternyata lebih mendominasi.

Apabila investorindividu masuk atau keluar dari pasar karena alasan likuiditas dan likuiditas bersifat musiman, maka pola perdagangan investor individual bersifat musiman. Hal ini disebabkan banyaknya pembayaran bulanan yang harus dilakukan pada saat mendekati akhir bulan sehingga pada saat tersebut diperlukan likuiditas yang lebih intensif. Oleh karena itu, investor individual cenderung membeli saham pada awal bulan dan menjualnya pada akhir bulan (Budileksmana, 2005).

\section{Rogalski Effect}

Rogalski effect merupakan suatu fenomena yang ditemukan oleh seorang peneliti bernama Robert J. Rogalski pada tahun 1984. Dalam penelitiannya, Rogalski (1984) menemukan adanya fenomena Monday effect di pasarAmerika. Dalam penelitiannya Rogalski mengelompokkan periode perdagangan ke dalam trading day and non trading day dimana return negatif terjadi selama periode nontrading. Selanjutnya Rogalski menemukan adanya hubungan yang menarik antara fenomena day of the week effect dengan January effect yaitu ditemukan bahwa rata-rata return hari Senin pada bulan Januari adalah positif sementara return pada bulan lainnya selain Januari adalah negatif.

Rogalski effect bisa diartikan sebagai suatu fenomena dimana return negatif yang biasa terjadi pada hari Senin (Monday effect) menghilang pada bulan tertentu. Hal ini disebabkan adanya kecendrungan return yang lebih tinggi pada bulan tersebut dibandingkan dengan bulan-bulan yang lainnya.

Banyak penelitian yang telah dilakukan di Indonesia untuk menyingkap fenomena January effect ini, akan tetapi beberapa penelitian menyimpulkan bahwa return bulan April lebih tinggi dibandingkan dengan return pada bulan lainnya atau lebih dikenal dengan sebutan 
April effect. Hal ini disebabkan oleh ketentuan yang ditetapkan oleh Badan Pengawas Pasar Modal No 80/PM/1996 yang menyatakan bahwa laporan tahunan harus disertai dengan laporan akuntan dengan pendapat yang lazim dan disampaikan kepada Bapepam 120 hari setelah tanggal tahun tutup buku perusahaan. Hal ini berarti bahwa laporan keuangan maksimum disampaikan pada bulan April (Hendi dan Darmadji dalam Irmani dan Mahdi, 2006).

Laporan auditormerupakan pengumuman yang dapat mempengaruhi harga sekuritas (Yogianto, 2014:589) sehingga dengan adanya laporan tersebut diperkirakanreturn saham pada bulan April akan lebih tinggi dibandingkan denganreturn saham pada bulan lainnya selain April.

\section{Volume Perdagangan Saham}

Volume perdagangan saham menunjukkan banyaknya lembar saham yang ditransaksikan selama periode waktu tertentu (Tandelilin, 2010). Secara teoritis, Karpoff (1986) mengemukakan bahwa perlakuan terhadap volume perdagangan saham dibagi atas tiga, yaitu:

1. Volume perdagangan saham berhubungan dengan bid-ask spread. Penelitian empiris mengindikasikan bahwa volume perdagangan saham secara negatif berhubungan dengan bid-ask spread, penemuan ini konsisten dengan beberapa model teoritis.

2. Volume perdagangan saham berhubungan dengan perubahan harga. Beberapa model teoritis mempertimbangkan hubungan volume perdagangan dengan perubahan harga. Epps memperoleh model dimana volume transaksi pada harga ticks-up lebih baik daripada volume saat downstick. Copeland menemukan bahwa volume setelah seluruh investor menerima informasi secara positif berhubungan dengan besarnya perubahan harga.

3. Volume perdagangan saham berhubungan dengan informasi, tetapi mengambil arah yang berbeda. Volume diperlakukan secara sederhana sebagai sejumlah transaksi antara pembeli dan penjual yang berpasangan secara acak pada periode perdagangan saham.

\section{Indeks LQ 45}

Informasi mengenai kinerja saham seringkali diringkas dalam suatu indeks yang disebut indeks pasar saham (stock market indexes). Indeks pasar saham adalah indikator yang menunjukkan pergerakan harga saham. Index berfungsi sebagai indikator tren pasar pada suatu saat, apakah pasar sedang aktif atau terlalu lemah (Maya \& Martalena, 2011:99). 
Pasar modal di Indonesia masih tergolong pasar modal yang transaksinya tipis (thin market) yaitu pasar yang sebagian besar sekuritasnya kurang aktif diperdagangkan sehingga IHSG yang mencakup semua saham yang tercatat dianggap kurang tepat sebagai indikator kegiatan pasar modal. Maka pada tgl 24 Februari 1997 dibentuk indeks LQ 45 yang terdiri dari hanya 45 saham-saham yang paling aktif diperdagangkan, yang diseleksi melalui beberapa kriteria pemilihan (Jogiyanto, 2014: 156)

\section{PENGEMBANGAN HIPOTESIS}

\section{Seasonality/Calendar Effect}

Hari Senin merupakan awal dari hari perdagangan setelah hari libur akhir pekan (non trading day). Dengan adanya hari libur tersebut menimbulkan kurang bergairahnya pasar modal dan mood investor dalam menanamkan modalnya, sehingga kinerja bursa akan rendah. Rendahnya kinerja pada hari Senin juga dapat diakibatkan karena perusahaan-perushaan emiten biasanya menunda pengumuman berita buruk (bad news) sampai dengan hari Jumat dan di respon oleh pasar pada hari Senin. Iramani dan Ansyori Mahdi (2006) berhasil membuktikan bahwa terjadi Monday effect di BEJ tahun 2005, Peneliti lain Hari Prasetyo (2006) membuktikan tidak terjadi day of the week effect di BEJ dilihat dari return dan abnormal return saham akan tetapi day of the week effect terjadi jika dilihat dari volatilitas return sahamdan juga penelitian yang dilakukan oleh Syahril, Indah, Riska (2014) tidak menemukan adanya Monday effect di BEI dengan periode penelitian tahun 2010-2013. Berdasarkan hasil penelitian sebelumnya maka hipotesa 1 adalah:

H1 : Volume Perdagangan Saham pada hari Senin cenderung lebih rendah dibandingkan hari lainnya (Seasonality/Calendar Effects).

\section{Week Four Effect}

Week four effect merupakan suatu fenomena yang mengungkapkan bahwa Monday effect hanya terjadi pada minggu keempat untuk setiap bulannya. Sedangkan return hari Senin pada minggu pertama sampai minggu ketiga dianggap tidak signifikan negatif. Sejumlah studi yang menghasilkan bukti empiris telah dilakukan untuk menguangkap adanya return negatif pada perdagangan hari Senin. Penelitian yang dilakukan oleh Iramani dan Ansyori Mahdi (2006) membuktikan bahwa Week four effect terjadi di BEJ pada tahun 2005. Peneliti 
selanjutnya Octavianus Pandiangan (2009), hasil uji One sample $T_{\text {test }}$ untuk membuktikan efek minggu keempat (week four effect) return saham di BEI pada tahun 2008 tidak terbukti terjadi, didukung oleh penelitian yang dilakukan Syahril, Indah, Riska (2014). Berdasarkan hasil penelitian sebelumnya maka hipotesa 2 adalah:

H2: Seasonality/Calandar Effects hanya terjadi pada hari senin minggu keempat setiap bulannya (week four effect).

\section{Seasonality/Calandar Effects menghilang pada bulan April (Rogalski Effect).}

Beberapa penelitian yang dilakukan pada Bursa Efek Jakarta menyimpulkan bahwa return pada bulan April lebih tinggi dibandingkan dengan bulan lainnya atau lebih dikenal dengan sebutan April effect. Hal ini disebabkan oleh ketentuan yang ditetapkan oleh Badan Pengawas Pasar Modal yang menyatakan bahwa laporan tahunan harus disertai dengan laporan akuntan dengan pendapat yang lazim dan disampaikan kepada Bapepam 120 hari setelah tanggal tahun tutup buku perusahaan. Hal ini berarti bahwa laporan keuangan maksimum disampaikan pada bulan April. Antariksa Budileksmana (2005) menemukan Rogalski effect terjadi di BEJ tahun 1999-2004 sedangkan peneliti terbaru yang dilakukan oleh Syahril, Indah, Riska (2014) tidak menemukan adanya Rogalski effect di BEI dengan tahun pengamatan 2010-2013. Berdasarkan hasil penelitian sebelumnya maka hipotesa 3 adalah:

H3 : Seasonality/Calandar effect menghilang pada bulan April (Rogalski effect).

\section{METODE PENELITIAN}

Sampel yang digunakan dalam penelitian ini adalah perusahaan-perusahaan yangkonsisten listing di Bursa Efek Indonesia indeks LQ-45 selama tahun 2010-2013. Pemilihan sampel dilakukan dengan metode purposive sampling yaitu pengambilan sampel yang dilakukan berdasarkan kriteria tertentu. (Sugiyono, 2007:85). Jumlah sampel yang sesuai dengan kriteria adalah sebanyak 24 perusahaan.

Data yang digunakan dalam adalah data sekunder yaitu data yang diperoleh secara tidak langsung tetapi melalui media perantarayang dipublikasikan dan yang tidak dipublikasikan (Indriantoro dan Supomo, 1999).Data volume perdagangan saham harian 
selama tahun 2010-2013 dan daftar perusahaan yang listing di LQ-45 tahun 2010-2013 diperoleh dari sumber http://finance.yahoo.com dan www.idx.co.id.

Penelitian ini merupakan penelitian komparatif yaitu suatu penelitian yang bersifat membandingkan (Sugiyono, 2007:11). Metode komparatif dipakai untuk mengetahui perbedaan rata-rata volume perdagangan saham pada setiap hari perdagangan. Pengujian penelitian ini menggunakan uji beda yang bertujuan untuk mencari perbedaan antara dua sampel data atau lebih.

\section{Variabel Penelitian}

Variabel dependen adalah variabel yang dipengaruhi atau menjadi akibat, karena adanya variabel bebas (Sugiyono, 2007:59).Variabel dependen yang digunakan dalam penelitian ini adalah volume perdagangan saham yang merupakan jumlah lembar saham yang diperdagangkan pada periode tertentu. Volume perdagangan saham pada penelitian ini adalah volume perdagangan saham harian pada saat penutupan.

Variabel indenpenden disebut juga variabel bebas. Variabel bebas merupakan variabel yang mempengaruhi atau menjadi sebab perubahannya atau timbulnya variabel dependen atau terikat (Sugiyono, 2007:59).Variabel independen yang digunakan dalam penelitian ini adalah seasonality/calendareffectyaitu volume perdagangan saham pada hari Senin, week four effectyaituvolume perdagangan sahampada hari Senin minggu ke-empat setiap bulannya dan Rogalski effectyaitu volume perdagangan saham pada bulan April untuk periode pengamatan bulan Januari-Desember 2010-2013.

\section{Metode Analisis Data}

\section{Analisis Deskriptif}

Analisis deskriptif dapat digunakan untuk menggambarkan dan menganalisa dengan cara mendeskripsikan data yang telah terkumpul sebagaimana adanya tanpa bermaksud membuat kesimpulan yang berlaku umum atau generalisasi (Sugiyono, 2007:147)

\section{Analisis Kuantitatif}

a. Uji Normalitas

Uji normalitas dilakukan untuk menguji apakah data yang digunakan memiliki distribusi normal atau mendekati normal. Metode pengujian normalitas yang dipakai 
adalah uji One-Sample Kolmogorov-Smirnov, apabila nilai signifikansi di atas 0,05 maka data berdistribusi normal dan sebaliknya jika signifikansi di bawah 0,05 maka artinya data tidak berdistribusi normal.

\section{b. Pengujian Hipotesis}

\section{1). Pengujian Hipotesis 1}

Untuk menguji hipotesis pertama yaitu bahwa volume perdagangan saham pada hari Senin cenderung lebih rendah dibandingkan hari lainnya (seasonality/calendar effect), digunakan Analisis One Way ANOVA (analysis of variance) adalah suatu metode untuk menguraikan keragaman total data menjadi komponen-komponen yang mengukur berbagai sumber keragaman. Analysis of variance digunakan untuk membandingkan nilai rata-rata tiga atau lebih sampel (Imam Ghozali, 2009:64).

Pada penelitian ini digunakan tingkat signifikansi sebesar $\alpha=5 \%$, dimana suatu model dianggap signifikan F jika memiliki nilai $\alpha<5 \%$.

Hipotesis statistik pengujiannya adalah sebagai berikut:

$\mathrm{H} 0: \mu \mathrm{sn}=\mu \mathrm{sl}=\mu \mathrm{rb}=\mu \mathrm{km}=\mu \mathrm{jm}$

$\mathrm{H} 1: \mu \mathrm{sn} \neq \mu \mathrm{sl} \neq \mu \mathrm{rb} \neq \mu \mathrm{km} \neq \mu \mathrm{jm}$

Dasar pengambilan keputusan :

Jika $\mathrm{F}_{\text {hitung }}<\mathrm{F}_{\text {tabel }}, \mathrm{H}_{0}$ diterima.Berarti tidak ada perbedaan yang nyata antara rata-rata volume perdagangan saham dari kelima hari perdagangan.

Jika $\mathrm{F}_{\text {hitung }}>\mathrm{F}_{\text {tabel}}, \mathrm{H}_{0}$ ditolak atau $\mathrm{H}_{1}$ diterima.Berarti ada perbedaan yang nyata antara rata-rata volume perdagangan saham dari kelima hari perdagangan.

\section{2). Pengujian Hipotesis 2}

Untuk menguji hipotesis kedua, yaitu week four effect di Bursa Efek Indonesia digunakan uji Independent sample $\mathrm{T}_{\text {test }}$ satu sisi kanan. Pengujian independent sample $T_{\text {test }}$ digunakan untuk menentukan apakah dua sampel yang tidak berhubungan memiliki nilai rata-rata yang sama ataukah tidak sama secara signifikan (Imam Ghozali, 2009:64). Adapun perumusan hipotesis statistiknya sebagai berikut: $\mathrm{H} 0=\mu 1 \leq \mu 2$ 
$\mathrm{H} 1=\mu 1>\mu 2$

$\mu 1=$ rata-rata volume perdagangan Senin selain minggu terakhir

$\mu 2=$ rata-rata volume perdagangan Senin minggu terakhir

Dasar pengambilan keputusan:

Hipotesis diterima apabila nilai t hitung $\leq \mathrm{t} 0.05$; df, maka artinya H0 tidak dapat ditolak karena tidak terjadiweek four effect di Bursa Efek Indonesia.

Hipotesis ditolak apabila nilai t hitung $>$ t0.05; df, maka artinya H0 di tolak karena terjadi week four effectdi Bursa Efek Indonesia.

\section{3). Pengujian Hipotesis 3}

Untuk menguji hipotesis kedua, yaitu Rogalski effect di Bursa Efek Indonesia juga digunakan uji Independent sample $T_{\text {test }}$ satu sisi kanan. Adapun perumusan hipotesis statistiknya sebagai berikut:

$\mathrm{H} 0=\mu 1 \leq \mu 2$

$\mathrm{H} 1=\mu 1>\mu 2$

$\mu 1=$ rata-rata volume perdagangan Senin pada bulan April

$\mu 2=$ rata-rata volume perdagangan Senin pada bulan selain April

Dasar pengambilan keputusan:

Hipotesis diterima apabila nilai $\mathrm{t}$ hitung $\leq \mathrm{t} 0.05$; df, maka artinya $\mathrm{H} 0$ tidak dapat ditolak karena tidak terjadi Rogalskieffect di Bursa Efek Indonesia.

Hipotesis ditolak apabila nilai t hitung $>$ t0.05; df, maka artinya H0 di tolak karena terjadi Rogalskieffect di Bursa Efek Indonesia.

\section{HASIL PENELITIAN DAN PEMBAHASAN}

\section{Analisis Statistik Deskriptif}

Table 1

\section{Satistik Deskriptif Rata-Rata Volume Saham Harian}

\begin{tabular}{|c|c|c|c|c|c|}
\hline Hari & $\mathrm{N}$ & Minimum & Maximum & Mean & Std. Deviation \\
\hline Senin & 199 & 15,2231 & 18,1754 & 17,007449 & 0,4277320 \\
\hline Selasa & 192 & 14,2858 & 18,2639 & 17,090505 & 0,4491865 \\
\hline
\end{tabular}




\begin{tabular}{|c|c|c|c|c|c|}
\hline Rabu & 201 & 16,1109 & 18,2782 & 17,182625 & 0,3450539 \\
\hline Kamis & 195 & 16,1351 & 18,0521 & 17,168783 & 0,3750185 \\
\hline Jum'at & 192 & 14,4747 & 18,2409 & 17,106267 & 0,4285923 \\
\hline Total & 979 & & & & \\
\hline
\end{tabular}

Sumber: Hasil Pengolahan Data dengan Menggunakan SPSS 20

Dari tabel 1 dapat dilihat bahwa rata-rata volume perdagangan saham adalah positif dan bersifat fluktuatif. Rata-rata volume perdagangan saham terendah terjadi pada hari Senin yaitu sebesar 17,007449 setelah itu terjadi kenaikan pada hari Selasa sebesar 17,090505. Pada hari Rabu meningkat menjadi 17,182625 namun menurun pada hari Kamis menjadi 17,168783 dan kembali menurun pada hari Jumat dengan rata-rata volume perdagangan sebesar $17,106267$.

Agar memberikan gambaran yang lebih jelas, maka disajikan fluktuasi rata-rata perdagangan saham harian pada gambar 1

\section{Gambar 1}

\section{Pergerakan Rata-Rata Volume Perdagangan Saham Harian}

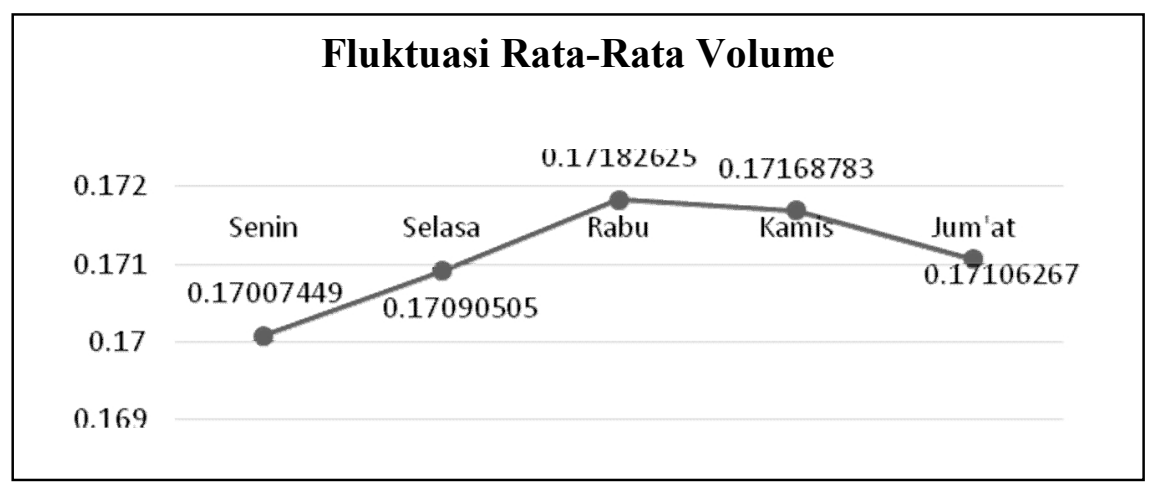




\section{Pengujian Normalitas Data}

Tabel 2

Hasil Uji Normalitas Data Dengan Metode

One-Sample Kolmogorov-Smirnov Test

\begin{tabular}{|l|l|r|}
\hline \multicolumn{2}{|l|}{} & \multicolumn{1}{c|}{ Volume } \\
\hline \multirow{2}{*}{ N } & & 979 \\
\hline \multirow{2}{*}{ Normal Parameters ${ }^{\mathrm{a}, \mathrm{b}}$} & Mean & 17,111219 \\
\cline { 2 - 3 } & Std. Deviation & 0,4105525 \\
\hline & Absolute & 0,041 \\
\cline { 2 - 3 } & Positive & 0,024 \\
\cline { 2 - 3 } & Negative & $-0,041$ \\
\hline Kolmogorov-Smirnov Z & & 1,280 \\
\hline Asymp. Sig. (2-tailed) & & 0,075 \\
\hline Sumber: Hasil Pengolahan Data dengan Menggunakan SPSS 20
\end{tabular}

Dari tabel2diatas diketahui bahwa nilai signifikansi (p) dariOne-Sample KolmogorovSmirnov Test sebesar 0,075. Nilai tersebut lebih besar dibandingkan dengan 0,05 (0,075> $0,05)$ dengan demikian dapat disimpulkan bahwa bahwa data yang digunakan berdistribusi normal sehingga pengujian berikutnya dapat dilakukan karena asumsi sudah terpenuhi.

\section{Pengujian Seasonality/Calendar Effect(H1)}

Hipotesis pertama dalam penelitian ini adalah bahwa volume perdagangan saham pada hari Senin di Bursa Efek Jakarta tahun 2010-2013 cenderung lebih rendah dibandingkan hari lainnya (seasonality/calendar effect). Pengujian hipotesis ini dilakukan dengan menggunakan Uji F One WayAnalysis of Variance (ANOVA). Syarat utama dalam melakukan uji ANOVA adalah data yang dipakai harus berdistribusi normal dan homogen.Tabel 3 adalah hasil uji normalitas dan homogenitas data. 
Table 3

Test of Homogeneity of Variances

\begin{tabular}{|c|c|c|c|}
\hline \multicolumn{4}{|c|}{ Volume } \\
\hline $\begin{array}{l}\text { Levene } \\
\text { Statistic }\end{array}$ & df1 & $\mathrm{df} 2$ & Sig. \\
\hline 1,514 & 4 & 974 & 0,196 \\
\hline
\end{tabular}

Sumber: Hasil Pengolahan Data dengan Menggunakan SPSS 20

Hasil Test of Homogeneiy of Variances menunjukkan tidak signifikan pada 0,05 $(0,196>0,05)$ yang berarti varian dari rata-rata volume perdagangan saham antar hari (Senin, Selasa, Rabu, Kamis dan Jum'at) adalah sama, data penelitian dapat dikatakan homogen (seragam). Karena homogenitas data terpenuhi, maka uji one way ANOVA dapat dilakukan. Hasil pengujian One WayANOVA terhadap rata-rata volume perdagangan saham 24 emiten LQ-45 selama tahun 2010-2013 dapat dilihat pada tabel4 berikut:

\section{Tabel 4}

\section{Hasil Uji F ANOVA}

\begin{tabular}{|c|c|c|c|c|c|}
\hline \multicolumn{6}{|l|}{ Volume } \\
\hline & $\begin{array}{l}\text { Sum of } \\
\text { Squares }\end{array}$ & $\mathrm{df}$ & $\begin{array}{c}\text { Mean } \\
\text { Square }\end{array}$ & $\mathrm{F}$ & Sig. \\
\hline Between Groups & 3,901 & 4 & 0,975 & 5,902 & 0,000 \\
\hline Within Groups & 160,944 & 974 & 0,165 & & \\
\hline Total & 164,845 & 978 & & & \\
\hline
\end{tabular}

Sumber: Hasil Pengolahan Data dengan Menggunakan SPSS 20

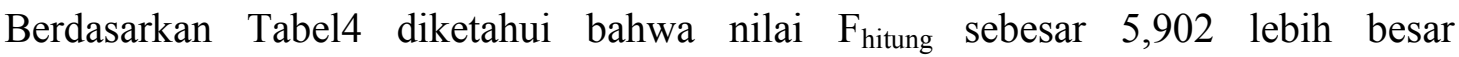
dibandingkan dengan nilai $\mathrm{F}_{\text {tabel }}$ sebesar 2,3811 yang menunjukkan ada perbedaan yang nyata antara rata-rata volume perdagangan saham dari kelima hari perdagangan. Tingkat signifikansi yang diperoleh adalah 0,000 yang lebih kecildari nilai signifikansi $0.05(0,00<$ 0,05)yang berarti $\mathrm{H}_{0}$ ditolak. Secara empiris hal ini membuktikan bahwa hari perdagangan berpengaruh secara signifikan terhadap volume perdagangan saham, artinya ada perbedaan rata-rata volume perdagangan saham antara hari Senin, Selasa, Rabu, Kamis dan Jum'at. 
Bukti ini sejalan dengan teori anomali pasar efisien yaitu adanya the day of the week effect, yang menyatakan bahwa terdapat perbedaan return saham dalam seminggu perdagangan. Berdasarkan deskripsi rata-rata volumeperdagangan saham harian (tabel 1), Monday effect dapat dilihat dari rata-ratavolume hari Senin yang merupakan rata-ratavolumepaling rendah dibandingkan hari perdagangan lainnya. Akan tetapi secara statistik, tidak dapat disimpulkan rata-rata volume terendah hanya dengan memperhatikan rata-rata dari setiap hari tersebut. Untuk menjawab pertanyaan hari manakah yang berbeda, maka statistik memiliki teknik post hoc test untuk mengetahui variabel manakah yang memiliki perberbedaan yang signifikan. Hasil uji Post Hoc Test volumeperdagangan saham hariSenin terhadap hari Selasa, Rabu, Kamis dan Jum'at dapat dilihat pada tabel berikut:

Tabel 5

\section{Post Hoc Test Multiple Comparisons}

Dependent Variable: Volume

Tukey HSD

\begin{tabular}{|c|c|c|c|c|c|c|}
\hline \multirow[t]{2}{*}{ (I) Hari } & \multirow[t]{2}{*}{ (J) Hari } & \multirow{2}{*}{$\begin{array}{c}\text { Mean } \\
\text { Difference (I-J) }\end{array}$} & \multirow[t]{2}{*}{ Std. Error } & \multirow[t]{2}{*}{ Sig. } & \multicolumn{2}{|c|}{$95 \%$ Confidence Interval } \\
\hline & & & & & Lower Bound & Upper Bound \\
\hline \multirow[t]{4}{*}{ Senin } & Selasa & $-0,0830596$ & 0,0411215 & 0,257 & $-0,195440$ & 0,029321 \\
\hline & Rabu & $-0,1751846^{*}$ & 0,0406503 & 0,000 & $-0,286277$ & $-0,064092$ \\
\hline & Kamis & $-0,1613334^{*}$ & 0,0409602 & 0,001 & $-0,273273$ & $-0,049393$ \\
\hline & Jum'at & $-0,0988225$ & 0,0411215 & 0,115 & $-0,211203$ & 0,013558 \\
\hline
\end{tabular}

Sumber: Hasil Pengolahan Data dengan Menggunakan SPSS 20

Tabel 5 adalah pengujian post hocs yang menunjukkan rata-rata perbedaan (mean difference) masing-masing hari perdaganganpada volume perdagangan saham antar hari pada 24 emiten LQ-45 selama tahun 2010-2013. Berdasarkan pada hasil Tukey HSD juga dapat disimpulkan bahwa terdapat perbedaan nyata rata-rata volume perdagangan saham pada 24 emiten LQ-45 selama tahun 2010-2013. Tingkat probabilitas signifikan volume perdagangan saham hari Senin dengan hari Rabu dan Kamis menunjukkan nilai lebih kecil dari 0,05yang membuktikan adanya perbedaan nyata terletak pada hari Senin dengan Rabu dan Kamis. 
Perbedaan rata-rata (mean difference)antara hari Senin dengan hari Rabu dan hari Kamis adalah -0,1751846dan -0,1613334. Tanda negatif pada main difference tersebut menunjukkan bahwa volume perdagangan saham pada hari Senin lebih rendah. Sedangkan untuk tingkat probabilitas rata-rata perbedaan volume perdagangan saham hari Senin dengan volume perdagangan saham hari Selasa dan Jum'at walaupun tidak signifikan pada 0,05 rata-rata volume perdagangan saham hari Senin dengan Selasa dan Jum'at menunjukkan probabilitas 0,257 dan 0,115 yang mengindikasikan adanya sedikit perbedaan nyata terletak pada hari Senin dengan hari Selasa dan Jum'at. Perbedaan rata-rata (mean difference)antara hari Senin dengan hari Selasa dan Jum'at juga negatif yaitu -0,0830596dan -0,0988225 yang menunjukkan bahwa volume perdagangan saham pada hari Senin lebih rendah. Peneliti menemukan rata-rata volume perdagangan saham terendah terjadi hari Senin sebesar 17,007449 dan rata-rata volume perdagangan saham tertinggi terjadi pada hari Rabu sebesar 17,182625 .

Hal ini berarti $\mathrm{H}_{0}$ dalam penelitian ini ditolak atau $\mathrm{H}_{1}$ diterima, dengan demikian membuktikan bahwa terjadi Seasonality/Calendar Effect di Bursa Efek Jakarta periode tahun 2010-2013. Terjadinya Monday effect dimana volume perdagangan saham yang paling rendah pada hari Senin di Bursa Efek Indonesia kemungkinan disebabkan oleh beberapa alasan diantaranya karenapara investor yang masih menunda melakukan pembelian saham di hari Senin, karena investor masih menentukan strategi dalam bertransaksi dengan terlebih dahulumelakukan pengkajian atas informasi yang masuk ke pasar, baik informasi domestik maupun informasi luar negeri juga informasi yang relevan yang biasanya dikeluarkan oleh perusahaan pada akhir pekan, umumnya perusahaan yang ingin menyampaikan informasi buruk (bad news) akan menunggu waktu yang tepat, yakni pada akhir pekan bertujuan agar para investor mempunyai waktu luang selama hari libur bursa (Sabtu dan Minggu) untuk mengevaluasi kembali kinerja emiten terhadap informasi yang ada tersebut, sedangkan investor berperilaku over raction terhadap suatu informasi yang buruk sehingga langsung menjual sahamnya dihari Senin.

Selain itu, Monday effect juga tidak terlepas dari sisi psikologi para investor yang cenderung tidak menyukai hari Senin sebaga awal hari kerja sehingga mereka pesimis saat bertransaksi di bursa. Peningkatan volume perdagangan saham yang terjadi di hari Selasa dan Rabu mungkin disebabkan karena hari tersebut investor sudah mulai menerapkan strategi investasinya. Strategi investasi yang digunakan adalah membeli saham-saham yang dipilih sehingga memungkinkan investor untuk memperoleh return positif. 


\section{Pengujian Week Four Effect (H2)}

Pengujian hipotesis kedua yaitu untuk membuktikan apakah volume perdagangan saham hari Senin minggu keempat setiap bulannya cenderung lebih rendah dibandingkan dengan volume perdagangan saham Senin selain minggu selain minggu keempat yaitu minggu pertama, kedua dan ketiga.

Hasil statistikdeskriptif mengenai rata-rata volume perdagangan saham Senin pada minggu keempat dan Senin selain minggu ke empat dapat dilihat pada tabel6.

\section{Tabel 6}

\section{Descriptive Statistic Week Four Effect}

\begin{tabular}{|l|l|r|r|r|c|}
\hline \multicolumn{7}{|c|}{ Group Statistics } \\
\hline \multicolumn{2}{|l|}{ Monday week four } & \multicolumn{1}{c|}{ N } & Mean & Std. Deviation & $\begin{array}{c}\text { Std. Error } \\
\text { Mean }\end{array}$ \\
\hline \multirow{2}{*}{ volume } & Minggu ke-4 & 48 & 16,967016 & 0,4270300 & 0,0616365 \\
\cline { 2 - 6 } & Mingguke 1-3 & 139 & 17,023864 & 0,4325798 & 0,0366909 \\
\hline
\end{tabular}

Sumber: Hasil Pengolahan Data dengan Menggunakan SPSS 20

Tabel 6 menjelaskan rata-rata volume perdagangan saham Senin minggu keempat pada emiten LQ-45 selama tahun 2010-2013 sebesar 16,967016 yang lebih kecil dibandingkan dengan rata-rata volume perdagangan saham Senin selain minggu keempat yaitu sebesar 17,023864. Rata-rata volume perdagangan saham pada Senin minggu keempat memiliki standar deviasi (variasi sebaran data) lebih kecil daripada nilai mean yang menunjukkan fluktuasi data variabel volume perdagangan saham selama periode pengamatan adalah rendah. Untuk melakukan uji statistik penelitian ini menggunakan Uji Independent Sample $T_{\text {test }}$, apakah terdapat perbedaan yang signifikan antara kedua sampel data tersebut. Hasil pengujian dapat dilihat pada tabel berikut: 


\section{Tabel 7}

\section{Hasil Pengujian Week Four Effect}

\begin{tabular}{|c|c|c|c|c|c|c|c|c|c|c|}
\hline \multicolumn{11}{|c|}{ Independent Samples Test } \\
\hline & & \multicolumn{2}{|c|}{$\begin{array}{c}\text { Levene's Test } \\
\text { for Equality of } \\
\text { Variances }\end{array}$} & \multicolumn{7}{|c|}{ t-test for Equality of Means } \\
\hline & & \multirow[t]{2}{*}{$\mathrm{F}$} & \multirow[t]{2}{*}{ Sig. } & \multirow[t]{2}{*}{$\mathrm{t}$} & \multirow[t]{2}{*}{ df } & \multirow[t]{2}{*}{$\begin{array}{l}\text { Sig. } \\
(2- \\
\text { tailed) }\end{array}$} & \multirow[t]{2}{*}{$\begin{array}{c}\text { Mean } \\
\text { Difference }\end{array}$} & \multirow[t]{2}{*}{$\begin{array}{l}\text { Std. Error } \\
\text { Difference }\end{array}$} & \multicolumn{2}{|c|}{$\begin{array}{c}95 \% \text { Confidence } \\
\text { Interval of the } \\
\text { Difference }\end{array}$} \\
\hline & & & & & & & & & Lower & Upper \\
\hline \multirow[t]{2}{*}{ volume } & $\begin{array}{l}\text { Equal } \\
\text { variances } \\
\text { assumed }\end{array}$ & 0,016 & 0,898 & $-0,788$ & 185 & 0,432 & $-0,0568485$ & 0,0721852 & - & 0,0855635 \\
\hline & $\begin{array}{l}\text { Equal } \\
\text { variances } \\
\text { not } \\
\text { assumed }\end{array}$ & & & $-0,793$ & 82,676 & 0,430 & $-0,0568485$ & 0,0717306 & $\begin{array}{r}- \\
0,1995260\end{array}$ & 0,0858291 \\
\hline
\end{tabular}

Sumber: Hasil Pengolahan Data dengan Menggunakan SPSS 20

Dari Tabel 7 memberikan hasil mengenai perbedaan antara rata-rata volume perdagangan saham hari Senin minggu keempat dengan rata-rata volume perdagangan saham hari Senin selain minggu keempat pada 24 emiten LQ-45 selama tahun 2010-2013 yang dapat dijelaskan sebagai berikut:

a. Nilai F sebesar 0.016 dengan signifikansi sebesar $0.898(0.898>0.05)$ yang menunjukkan bahwa terdapat perbedaan varians yang tidak signifikan antar kedua sampel data (ratarata volume perdagangan saham hari Senin minggu keempat dengan rata-rata volume saham hari Senin selain minggu keempat) tersebut, data penelitian dapat dikatakan homogen (seragam). Dengan demikian homogenitas data sebagai syarat untuk melakukan Independent Sampel Test terpenuhi.

b. NilaiT hitung volume perdagangan saham hari Senin minggu keempat adalah sebesar 0,7881ebih kecil dari pada $\mathrm{T}_{\text {tabel }} 1.65315(-0,788<1.65315)$ dengan tingkat signifikansi sebesar 0.432yang lebih besar dari 0.05 (0.432>0.05). Hal ini menunjukkan bahwa tidak terdapat perbedaaan yang signifikan antara rata-rata volume perdagangan saham Senin 
pada minggu keempat dengan rata-rata volume perdagangan saham Senin selain minggu keempat.

c. Meskipun perbedaan rata-rata (mean difference) kedua kelompok adalah negatif yaitu 0,788 dan -0,793 yang menunjukkan volume perdagangan saham minggu pertama, kedua dan ketiga lebih tinggi dibandingkan dengan volume perdagangan saham minggu keempat, hal ini juga dapat dibuktikan dengan membandingkan mean pada tabel statistik deskriptif diatas, akan tetapi perbedaan tersebut tidak signifikan.

Dengan demikian maka $\mathrm{H}_{0}$ tidak dapat ditolak, hal ini dapat dijelaskan bahwa tidak terjadi fenomena week four effectdi Bursa Efek Indonesia pada perusahaan LQ45 untuk periode pengamatan tahun 2010-2013pada perusahaan LQ45. Fenomena week four effect biasanya disebabkan karena adanya tuntutan untuk memenuhi segala kebutuhan utama yang harus dilakukan pada akhir bulan atau awal bulan berikutnya, oleh karena itu pada akhir bulan banyak terjadi tekanan jual sehingga harga saham akan turun, akan tetapi kemungkinan karena perkembangan pasar modal yang tidak pasti disebabkan oleh kondisi ekonomi dan politik baik dunia maupun dalam negeri membuat para investor enggan untuk berbelanja saham meskipun telah terjadi penurunan harga saham. Investor lebih memilih untuk menahan modalnya dan berhati-hati dalam berinvestasi, berartiteori week four effect yang mengatakan return signifikan negatif pada hari Senin minggu terakhir setiap bulannya tidak terbukti.

Temuan ini sejalan dengan penelitian yang dilakukan oleh Syahril, Indah dan Riska (2014) yang juga tidak berhasil menemukan rata-rata return hari Senin pada akhir bulan adalah negatif signifikan walaupun rara-rata return saham hari Senin minggu keempat cenderung negatif dibandingkan dengan rata-rata return saham hari Senin selain minggu keempat, seasonality day effect di Bursa Efek Indonesia tidak terkonsentrasi pada hari Senin minggu keempat setiap bulannya.

\section{Pengujian Rogalski Effect (H3)}

Hipotesis yang ketiga dalam penelitian ini adalah untuk untuk membuktikan apakah volume perdagangan saham hari Senin bulan April cenderung lebih tinggi dibandingkan dengan volume perdagangan saham pada hari Senin selain bulan April. Hasil deskripsi statistik mengenai rata-rata volume perdagangan saham Senin pada minggu keempat dan selain minggu ke empat dapat dilihat pada tabel pada tabel 8 


\section{Tabel 8}

\section{Descriptive StatisticVolume April dan Non-April}

\begin{tabular}{|l|l|r|r|r|r|}
\hline \multicolumn{5}{|c|}{ Group Statistics } \\
\hline \multicolumn{2}{|c|}{ Rogalski Effect } & N & Mean & $\begin{array}{c}\text { Std. } \\
\text { Deviation }\end{array}$ & Std. Error Mean \\
\hline \multirow{2}{*}{ Volume } & Senin April & 18 & 16,953317 & 0,4482509 & 0,1056537 \\
\cline { 2 - 6 } & Senin Selain April & 181 & 17,012832 & 0,4265576 & 0,0317058 \\
\hline
\end{tabular}

Sumber: Hasil Pengolahan Data dengan Menggunakan SPSS 20

Tabel 8 menjelaskan bahwa rata-rata volume perdagangan saham harian 24 emiten LQ-45 selama tahun 2010-2013 pada hari Senin bulan April sebesar 16,953317 yang lebih kecil dibandingkan dengan rata-rata volume perdagangan saham Senin selain bulan April yaitu sebesar17,012832.Rata-rata volume perdagangan saham pada Senin bulan Aprilmemiliki standar deviasi (variasi sebaran data) lebih besar daripada Senin selain Aprilyang menunjukkan fluktuasi data variabel volume perdagangan saham selama periode pengamatan lebih tinggi.

Perbedaan volume perdagangan saham hari Senin bulan April dan Senin selain bulan April dapat dilihat dari metode analisis Independent Sample $T_{\text {tes }} t$ sebagai berikut:

Tabel 9

\section{Hasil Uji Independent Sample Test}

Independent Samples Test

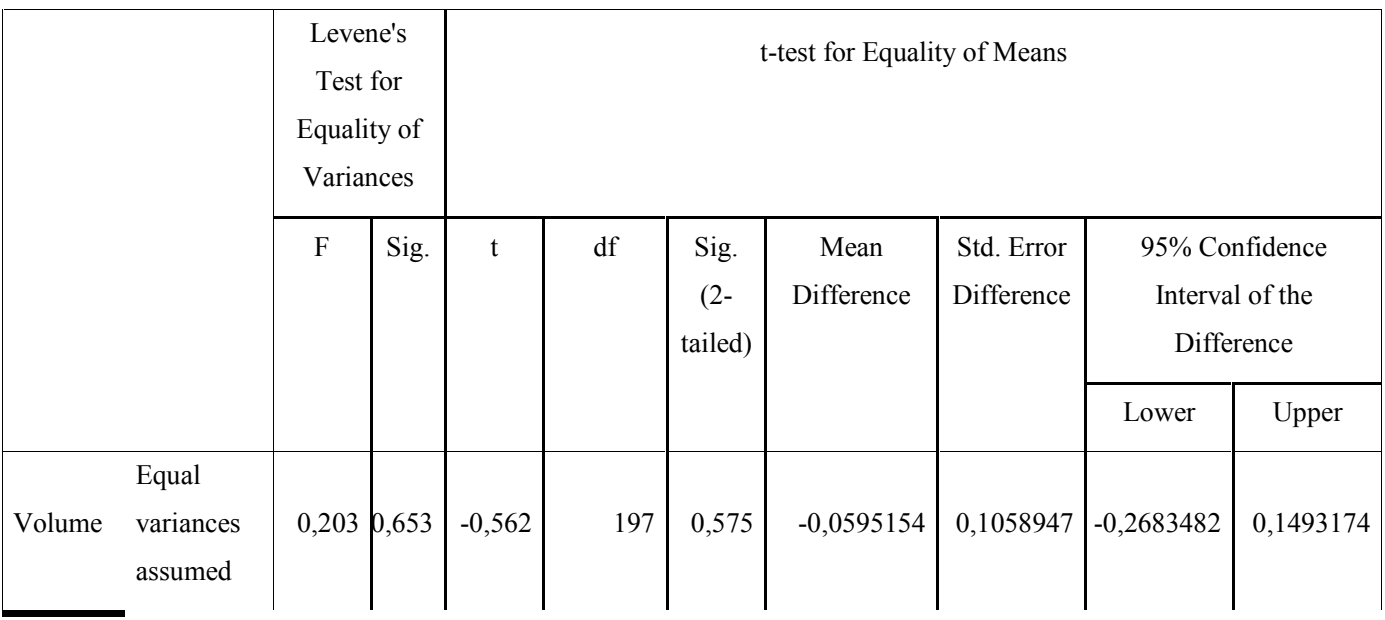




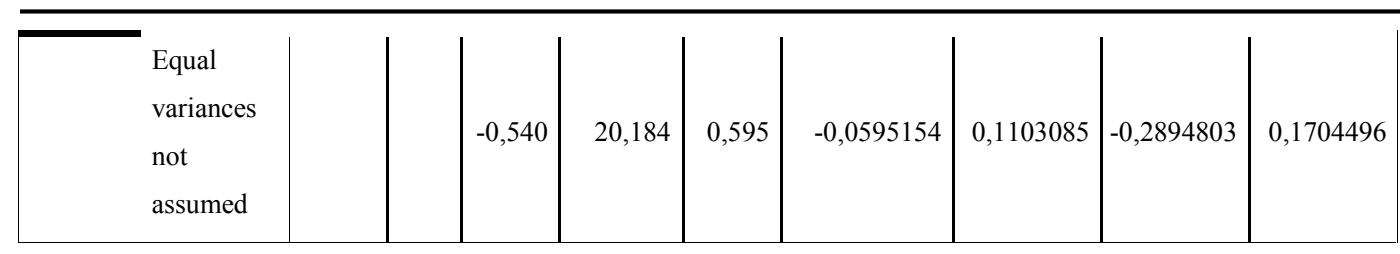

Sumber: Hasil Pengolahan Data dengan Menggunakan SPSS 20

Dari Tabel 9 memberikan hasil mengenai perbedaan antara rata-rata volume perdagangan saham hari Senin pada bulan April dengan rata-rata volume perdagangan saham hari Senin selain selain bulan April pada rata-rata volume perdagangan harian saham 24 emiten LQ-45 selama tahun 2010-2013 yang dapat dijelaskan sebagai berikut:

a. Nilai F sebesar 0.203 dengan signifikansi sebesar $0.653(0.653>0.05)$ yang menunjukkan bahwa terdapat perbedaan varians yang tidak signifikan antar kedua sampel data (ratarata volume perdagangan saham hari Senin bulan April dengan rata-rata volume perdagangan saham hari Senin selain minggu keempat) tersebut, data penelitian dapat dikatakan homogen (seragam). Dengan demikian homogenitas data sebagai syarat untuk melakukan Independent Sampel Test terpenuhi.

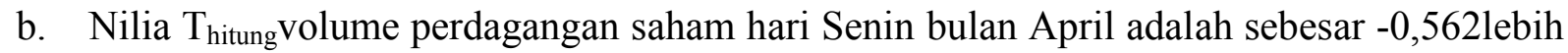
kecil dari pada $\mathrm{T}_{\text {tabel }} 1,65263(0,562<1,65263)$ dengan tingkat signifikansi sebesar 0,575 yang lebih besar dari $0,05(0,575>0,05)$. Hal ini menunjukkan bahwa tidak terdapat perbedaaan yang signifikan antara rata-rata volume perdagangan saham Senin pada bulan April dengan rata-rata volume perdagangan saham hari Senin selain bulan April.

c. Perbedaan rata-rata (mean difference) kedua kelompok adalah sama dan negatif yaitu 0,0595154 menunjukkan volume perdagangan saham selain bulan April lebih tinggi dibandingkan dengan volume perdagangan saham bulan April, hal ini juga dapat dibuktikan dengan membandingkan mean pada tabel statistik deskriptif diatas.

Jika dilihat berdasarkan rata-rata volume perdagangan saham maka sudah dapat dilihat bahwa volume perdagangan saham pada hari Senin bulan April tidak lebih besar dari pada volume perdagangan saham hari Senin selain bulan April bahkan volume perdagangan saham pada hari Senin bulan April lebih rendah dibanding volume perdagangan saham hari Senin selain bulan April. Dan berdasarkan alat uji hipotesisnya perbedaan tersebut tidak signifikan. Dengan demikian hipotesis nol pada penelitian ini tidak dapat ditolak.Hal ini dapat dijelaskan bahwatidak terjadi fenomena Rogalski effect di Bursa Efek Indonesia pada perusahaan LQ45 untuk periode pengamatan selama 2010-2013. 
Rogalski effect merupakan suatu kondisi perdagangan saham dimana seasonality/callendar effect menghilang pada bulan tertentu, dalam hal ini bulan April karena adanya ketentuan bahwalaporan tahunan harus disertai dengan laporanakuntan dengan pendapat yang lazim dan disampaikan 120 hari setelahtanggal tahun tutup buku perusahaan. Hal iniberarti bahwa laporan keuangan maksimumdisampaikan pada bulan April. Denganadanya praktik manajemen laba yang dilakukanoleh perusahaan terhadap laporan keuangannya,menyebabkan sentimen positif bagi perusahaan karena pasar menganggap kinerja perusahaan dalam keadaan yang cukup baik dan memiliki prospek yang baik untuk masa depan. Sehingga return pada bulan April lebih tinggi dari bulan bulan lainnya.

Dalam penelitian ini tidak ditemukan terjadinya fenomena Rogalski effect di Bursa Efek Indonesia pada perusahaan LQ45 untuk periode pengamatan selama 2010-2013. Dapat dilihat bahwa volume perdagangan saham tidak mengalami peningkatan setelah penerbitan laporan keuangan, hal ini terjadi kemungkinan informasi akuntansi hanya merupakan sumber informasi yang memberikan efek relatif kecil dibandingkan dengan informasi lainnya di pasar modal seperti informasi politik dan ekonomi.

\section{KESIMPULAN DAN SARAN}

\section{Kesimpulan}

Berdasarkan hasil pengujian dan analisis terhadap hipotesis yang telah diuraikan pada bab sebelumnya, maka penulis mengambil kesimpulan sebagai berikut:

1. Hasil uji yang dilakukan terhadap rata-rata volume perdagangan sahamharian pada 24 perusahaan LQ 45 selama tahun 2010-2013 dengan menggunakan metode One Way ANOVA berhasil membuktikan bahwa volume perdagangan terendah terjadi pada hari Senin. Dengan kata lain pada penelitian ini ditemukan adanya Monday effect di Bursa Efek Indonesia pada perusahaan LQ45 selama tahun 2010-2013.

2. Hasil uji Independent Sample $T_{\text {test }}$ ada penelitian ini menemukan bahwa rata-rata volume perdagangan saham hari Senin minggu keempat lebih rendah atau cenderung negatif di bandingkan dengan rata-rata volume perdagangan saham hari Senin selain minggu keempat, akan tetapi hasilnya menunjukkan perbedaan yang tidak signifikan. Temuan ini menjelaskan bahwa seasonality/calendar effectdi Bursa Efek Indonesia untuk perusahaan LQ45 selama tahun 20102013 tidak terkonsentrasi pada hari Senin minggu keempat setiap bulannya. Dengan kata lain, fenomena week four effecttidak terjadi di Bursa Efek Indonesia pada perusahaan LQ45 selama tahun 2010-2013. 
3. Data rata-rata volume perdagangansaham harian pada perusahaan LQ45 selama tahun 2010-2013 yang diuji dengan metode Independent Sample $T_{\text {test }}$ tidak berhasil menemukan bahwa volume perdagangan saham negatif yang terjadi pada hari Senin menghilang pada bulan tertentu yaitu bulan April. Peneliti bahkan menemukan bahwa rata-rata volume perdagangan saham hari Senin pada bulan April lebih rendah dibandingkan dengan rata-rata volume perdagangan sahamhari Senin pada bulan selain April. Dengan kata lain, tidak terjadi fenomena Rogalskieffect di Bursa Efek Indonesia pada perusahaan LQ45 selama tahun 2010-2013.

4. Hasil penelitian ini menunjukkan bahwa terjadinya anomali efisiensi pasar di BEI adalah bukti bahwa teori hipotesis pasar efisien (EMH)tidak konsisten, dimana semua informasi di pasar modal yang diserap oleh para pelaku pasar seperti investor, emiten dan penjamin dipengaruhi oleh efek hari perdagangan yang berbeda.

\section{Keterbatasan Penelitian dan Saran}

1. Variabel yang digunakan dalam penelitian ini hanya terbatas pada volume perdagangan saham,sedangkan pada pasar modal ada banyak variabelyang dapat digunakan seperti return realisasi, abnormal return,jumlah permintaan dan penawaran (bid/offer). Dengan demikianuntuk penelitian selanjutnya sebaiknya menggunakanvariabel-variabel yang berbeda dari penelitian ini.

2. Periode pengamatan pada penelitian ini adalah empat tahun, untuk peneliti selanjutnya bisa memperpanjang waktu pengamatan agar diperoleh hasil penelitian yang lebih baik lagi.

3. Sampel yang digunakan dalam penelitian ini adalah emiten LQ45, sedangkan banyak klasifikasi emiten yang terdapat di pasar modal. Peneliti berikutnya perlu melakukan analisis terhadap kelompok emiten yang lain ataupun terhadap semua emiten yang listed di BEI agar dapat menangkap respon seasonality/calender effect dan volatilitas saham. 


\section{REFERENSI}

AntariksaBudileksamana, 2005. Fenomena The Monday Effect di Bursa Efek Jakarta, SNA VIII, Solo, September 2005:491-503

Fama, Eugene F., 1970.Efficient market: A review of theory and empirical work, Journal of Finance, 25 (2): 383-417.

Gumanti, Tatang Ary dan Elok Sri Utami. 2002. Bentuk Pasar Efisien dan Pengujiannya. Jurnal Akuntansi dan Keuangan, Vol. 4, No. 1, hal. 54-68.

Ghozali, Imam, 2007. Aplikasi Analisis Multivariative dengan Program SPSS. Cetakan IV. Semarang: Badan Penerbitan Universitas Diponegoro.

Hartono, Jogiyanto, 2014. Teori Portofolio dan Analisis Investasi. Edisi kesembilan. BPFE, Yogyakarta.

Husnan, Suad, 2001. Teori Portofolio dan Analisis Sekuritas. Edisi ketiga, UPP AMP YKPN, Yogyakarta.

Hari Prasetyo, 2006. Analisis Hari Perdagangan Terhadap Return, Abnormal Return dan Volatilitas Return Saham (Studi Pada LQ-45 Periode Januari-Desember 2015). Tesis Universitas Diponegoro. Semarang

Indriantoro \& Supomo,1999. Metode Penelitian Bisnis untuk Akuntansi dan Manajemen. Edisi Pertama, BPFE yogyakarta.

Karpoff, J. M.,1986. A Theory of Trading Volume. The Journal of Finance 41(5), 1069-1087

Maya \& Martalena, 2011. Pengantar Pasar Modal. Edisi Pertama, Andi, Yogyakarta

OctavianusPandiangan, 2009. Analisis Anomali Pasar Hari Perdagangan pada Return Saham di Bursa Efek Indonesia. Jurnal Manajemen dan Bisnis.

Phaisarn Sutheebanjard\& Wichian Premchaiswadi, 2010. Analysis of Calendar Effects: Dayof-the-Week Effect on the Stock Exchange of Thailand (SET) International Journal of Trade, Economics and Finance, Vol. 1, No. 1, June, 2010, 2010-023X

Rogalski R.J., 1984. New Finding Regarding Day of The Week Returns Over Trading and Non-Trading Periods: A Note. Jurnal of Finance Vol. 39 No. 5, pp: 1603-1614 
Rr Iramani \&Ansyori Mahdi, 2006. Studi tentang Pengaruh Hari Perdagangan terhadap Return Saham pada Bursa Efek Jakarta. Dalam Jurnal Akuntansi dan Keuangan, 8(2): h:63-70.

Sufren, 2014. Belajar otodidak SPSS Pati Bisa. Edisi Pertama. Elex Media Computindo, Jakarta.

Syahril, Indah \& Riska, 2014. Model Efisiensi Pasar: Sebuah Studi Pengaruh Musiman di BEI Emiten LQ 45 Tahun 2010-2012.

Sugiyono, 2007. Metode Penelitian Kuantitatif, Kualitatif \& RND. Alfabeta, Bandung

Siqi Guo \& Zhiqiang Wang, (2007), Thesis, Market efficiency anomalies, A study of seasonality effect on the Chinese stock exchange.

Tandelilin, Eduardus, 2010. Portofolio dan Investasi Teori, Edisi Pertama. Konisius, Yogyakarta

http://www.idx.co.id, diakses tanggal 20 April 2015

http://finance.yahoo.com, diakses tangal 02 Mei 2015 